\title{
CERAMIC PETROGRAPHY
}

Andrew Middleton*

MIDDLETON, A. Ceramic petrography. Rev. do Museu de Arqueologia e Etnologia, São Paulo, Suplemento 2: 73-79, 1997.

RESUMO: O objetivo deste artigo é indicar o potencial da petrografia cerâmica no fornecimento de informações arqueologicamente úteis sobre a cerâmica antiga. $O$ lado prático da técnica é ressaltado, em especial a necessidade de amostragem destrutiva de fragmentos cerâmicos. São descritos também alguns aspectos históricos do desenvolvimento desta técnica. As possibilidades (e limitações) do método de estudo da tecnologia cerâmica e da determinação de proveniência são discutidas e ilustradas através de estudos de caso já publicados.

UNITERMOS: Petrografia cerâmica — Tecnologia cerâmica — Proveniência cerâmica.

\section{Introduction}

This paper is intended to provide an introduction to the application of petrographic techniques to archaeological ceramic materials ${ }^{1}$ Some historical background is given concerning its introduction to archaeology and a very brief indication of the practicalities of the technique is also provided. However, the main aim has been to indicate the nature of the information that can be obtained from petrographic studies, illustrated where appropriate by brief reference to case studies. The paper is not intended to be either a practical guide to the application of petrographic methods nor a comprehensive review of published work on the subject.

(*) Department of Scientific Research, British Museum, London .

(1) This paper is based upon a lecture given at the International Symposium 'Análises Físicas e Químicas no Estudo de Material Arqueológico' held in São Paulo in May 1996. I am grateful to the organisers and sponsors for the opportunity to attend the conference. I am also grateful to several colleagues for useful discussions which have contributed to the views expressed here. Particular thanks are due to Ian Freestone of the British Museum, Department of Scientific Research.
For these the reader is referred to other publications cited in the text ${ }^{2}$

Ceramic petrography was introduced to the archaeological community by the work of Anna Shepard, particularly by her book, Ceramics for the archaeologist, first published in 1956 (Shepard, 1956). The technique had been applied by others to contemporary ceramics (see for example, Simcock, 1956) and also to archaeological material $^{3}$ but its potential was not widely appreciated

(2) An article reviewing the applications and philosophy of ceramic petrography was published by Freestone (1995), together with an article by Vaughan on specific applications of the technique to ceramics from the Aegean (Vaughan, 1995). Two collections of papers describing applications of ceramic petrography to archaeological material derived from a variety of cultures have been published by the British Museum: Freestone et al. (1982), Middleton and Freestone, 1991; a volume edited by Méry (1992) on archaeological applications of the techniques of Earth Sciences includes several papers on the use of petrography. Similarly, the proceedings of the European Ceramic Society Conferences (e.g. Fabbri, 1995) include papers describing applications of petrography to archaeological ceramics.

(3) In a review of the scientific methods available for the analysis of ancient ceramics, Peacock (1970) refers to several petrographic studies published in the 1930s to 1960s. 

1997.

until Shepard's ground-breaking studies of glazepaint pottery from Rio Grande during the 1940s (Shepard, 1942, 1966). These studies highlighted the potential role of petrographic examination, because Shepard's results overturned what was then the current archaeological understanding of the production of this pottery: despite some typological similarities between pottery from different sites, it had been thought that the pottery was locally made but Shepard's work showed that there was, in fact, evidence for extensive movement of pottery. Underlying the success of her examination of the glaze-paint pottery was the fact that the geology of the region is varied, so that the mineralogical composition of the clay pastes varied from place to place.

A similarly favourable geological circumstance contributed to the pioneering work of David Peacock in Britain during the 1960s (Peacock, 1969). Like Shepard, Peacock was able to demonstrate the potential of ceramic petrography to characterise groups of vessels on the basis of their fabrics. Peacock's study also illustrated very clearly the predictive quality of petrography, that is its ability to propose possible geographical source areas on the basis of geologically distinctive clay pastes. Thus he was able to suggest that some types of Glastonbury Ware, a very widespread group of Iron Age pottery, were made from a very distinctive clay found on the Lizard Peninsular of Cornwall, in southwestern Britain.

Ceramic petrography is a destructive technique, although this is only occasionally a serious disincentive to its use. It requires the preparation of a thin section from a coherent slice of pottery removed from a sherd (or vessel, on the rare occasions when this is acceptable). The slice is polished flat, mounted on a glass slide and ground to a thickness of $0.03 \mathrm{~mm}(30 \mu \mathrm{m})$ (Hutchinson, 1974). A thin glass coverslip may be added or the section left uncovered, which facilitates examination in the scanning electron microscope ${ }^{4}$. At this thickness of $30 \mu \mathrm{m}$ many of the minerals that make up the ceramic paste are translucent, so that their optical properties can be observed using a petrographic (polarising) microscope. This technique is widely used by geologists and miner-

(4) The application of the analytical scanning electron microscope to archaeological artefacts, including ceramics, was discussed by Freestone and Middleton (1987). alogists, and the characteristic optical properties of minerals are well known ${ }^{5}$ On this basis, it is possible to identify the minerals in the thin section, although some allowance may be necessary in some instances for the effects that firing of the clay paste may have had on those properties (Rigby, 1948).

Thus, examination of ceramics in thin section can yield information on the nature of the clay paste; in particular it can be used to identify and characterise (e.g. by size, shape and abundance) the inclusions in the clay. Observations of the fine clay matrix itself are often less diagnostic, because of the very small grain size of the clay minerals. Nevertheless it is usually possible to make some comments on features such as colour, homogeneity and on any evidence for general alignment of the clay particles that may have arisen during preparation of the clay or in forming the vessel.

\section{Information from petrography}

The information to be gained from petrographic study of archaeological ceramics will be considered under two broad headings, technology and characterisation/provenance.

\section{Ceramic technology}

Petrographic observations may provide evidence on several aspects of ceramic technology, from the selection and preparation of the clay paste, through the modification of its properties by deliberate additions, to the technique used to form the vessels. Observation of the thin section may show that the clay paste is inhomogeneous, perhaps providing evidence for the (imperfect) mixing of more than one clay source by the potter.

\section{- Temper}

The clays used to make pottery may have been obtained from primary geological sources (i.e.

(5) A useful set of four profusely illustrated atlases of photomicrographs of a very wide selection of rocks and minerals has been published by Mackenzie and others: Mackenzie and Guilford, 1980; Mackenzie et al., 1982; Adams et al., 1984; Yardley et al., 1990. More recently a condensed compendium volume, which also provides a simple introduction to optical mineralogy, has been published (Mackenzie and Adams, 1994). 
sedimentary clay rocks) or from secondary sources derived from pre-existing rocks by weathering, and perhaps redistributed and deposited by rivers as alluvium. Such clays frequently contain solid (aplastic) inclusions of rocks and minerals which reflect the geology of the source area; such inclusions are termed natural or intrinsic. However, aplastic material may also be added by the potter, to modify the properties of the clay. Such additions are frequently known as temper, although this term is sometimes used also to describe intrinsic inclusions. Inclusions may include materials such as quartz sand, chert (i.e. silex, flint), fragments of crushed rock, shell or bone. The charred remains of carbonaceous organic materials (such as chaff or dung) or the voids left after such material has burned out may also be seen in thin section. Man-made materials, most notably grog (i.e. crushed fired ceramic or chamote) may sometimes be recognised by microscopical observation, although this is not always straightforward (Whitbread, 1986; Cuomo di Caprio and Vaughan, 1993). Fragments of slag derived from metal extraction/working activities may also be encountered.

Thus, characterisation of the aplastic inclusions may provide evidence for the deliberate addition of particular types of temper or opening material. For instance, many cooking pots of Bronze Age date from the Near East are found to be tempered with crushed calcite. This material is very distinctive in thin section, comprising sharply angular, rhomb-shaped particles. Why was this material so widely used as temper? There may have been underlying technical reasons for its selection as the tempering material for cooking pots. Calcite has a rate of expansion on heating which is very similar to that of typical low-fired clay (Rye, 1976), so that it is a very suitable material, avoiding problems of thermal stress when the vessel is heated. However, its use is not without disadvantage and the firing temperature must be carefully controlled to avoid the problem of lime-blowing. This phenomenon may cause severe damage or even the total disintegration of the vessel: calcite, destroyed during firing, slowly reforms as indicated in the following equations:

$$
\begin{aligned}
& \text { (1) } \mathrm{CaCO}_{3} \rightarrow \mathrm{CaO}+\mathrm{CO}_{2} \uparrow \\
& \text { heat }
\end{aligned}
$$

[calcite destroyed on firing $>750^{\circ} \mathrm{C}$
(2) $\mathrm{CaO}+\mathrm{H}_{2} \mathrm{O} \rightarrow \mathrm{Ca}(\mathrm{OH})_{2}$ [portlandite formed on exposure to water vapour in the atmosphere]

(3) $\mathrm{Ca}(\mathrm{OH})_{2}+\mathrm{CO}_{2} \rightarrow \mathrm{CaCO}_{3}+\mathrm{H}_{2} \mathrm{O}$

[fine-grained calcite reformed by reaction with $\mathrm{CO}_{2}$ in the atmosphere]

Stage (2) in this process, the formation of portlandite, involves a large increase in volume and it is this that leads to lime-blowing. This problem and possible ways of avoiding it, including the use of salt, were discussed by Rye (1976) in the context of his seminal study of contemporary pottery making in Papua. Further discussion has ensued (see, for example, Rice, 1987 and references therein) but is beyond the scope of this paper.

Technological arguments such as this cannot, however be pursued too far, for many cooking pots are not tempered with calcite. In a study of British cooking vessels Woods (1986) showed that many were tempered with sand consisting mainly of quartz. This is surprising because the thermal expansion characteristics of quartz would appear to be very unhelpful (quartz shows a very marked increase in volume as it is heated above $573{ }^{\circ} \mathrm{C}$ ) but it is clear that vessels tempered with quartz sand were widely produced and used (presumably with reasonable success), even though they may not have been as technically sophisticated as calcitetempered vessels.

Another commonly used tempering material was shell, both fossil shell (i.e. derived from geological sedimentary rocks) and contemporary, modern shell. Shell is a very tough material and can be very difficult to crush. This problem can be alleviated by calcining the shell before use. In addition to reducing the toughness of the shell, this also serves to convert the aragonite mineral (of which most shell consists) to calcite. Thus, calcined shell will offer the same advantage as crushed calcite in respect of reduced thermal stress. Additionally, it confers greater mechanical strength because of the elongate, platy shape of the crushed shell fragments. Shell will of course present the problem of lime-blowing, in the same way as calcite.

Grog (chamote) is also widely found as temper; this material may be obtained by crushing either pre-existing pottery or specially prepared fired clay. As might be expected, grog has a thermal expansion 
coefficient which closely matches typical fired clay, making it a very appropriate tempering material from a technological viewpoint.

\section{Forming technique}

Another aspect of ceramic technology studies to which petrographic observations may contribute is the elucidation of forming techniques. The various forming processes (e.g. coil building, slab building, wheel-turning) impart various degrees and different directions of preferred orientation to the clay platelets, inclusions and voids in the ceramic paste (Rye, 1977). These can sometimes be observed in thin section, along with the joins between the various elements of clay used in coil building and slab building (Woods, 1985; Courty and Roux, 1995). Often though other techniques, such as radiography may be useful and also less destructive for this type of investigation (Middleton, 1997).

\section{Firing}

Much prehistoric pottery was fired at relatively low temperatures $\left(<800^{\circ} \mathrm{C}\right)$ in open bonfire or pit firings. Ethnographic evidence (see for example, Woods, 1982) suggests that these firings may have been of short duration, typically about an hour. Under these conditions, although the clay structure may be modified, it frequently retains optical activity when observed in the petrographic microscope. At higher temperatures the original crystalline structure is destroyed and the clay is transformed into an amorphous glassy matrix which is optically isotropic. In this way examination in the petrographic microscope may provide some indication of the temperature at which the pottery was fired. However, direct observation of the degree of vitrification of the clay matrix in the scanning electron microscope usually provides a more convenient and informative approach to the estimation of pottery firing temperatures. Similarly, the examination of vitrification textures in samples of refractory debris from furnaces, permits the estimation of the temperature of processes such as metal smelting ${ }^{6}$

(6) In a series of papers, Tite and his colleagues (e.g. Maniatis and Tite, 1981) showed that there are progressive changes in the vitrification textures of ceramics as they are exposed

\section{Characterisation and Provenance}

Ceramic fabrics may be characterised by geologically distinctive inclusions: the Glastonbury Ware pottery studied by Peacock and referred to in the Introduction, was found to contain inclusions of an altered gabbro rock. Peacock noted that these inclusions were similar to rocks which, within the geographical region of interest, are to be found only on the Lizard Peninsular in South-west England, so that he was able to propose that the Lizard areas was the source of the Glastonbury ware sherds made in this particular fabric.

A study of some pottery from Hengistbury Head, an Iron Age hill fort on the south coast of England (Freestone and Rigby, 1982), provides another example of the use of petrographic analysis to suggest the provenance of pottery. Freestone showed that the local coarsewares were predominantly in fabrics containing quartz sand, whilst a group of finewares was characterised by a very different fabric containing distinctive inclusions of amphibole, a mineral characteristic of metamorphic rocks. There are no potential sources of such rocks in this part of southern England and the most likely source is the Brittany region of France. This conclusion that the pottery was imported was supported by typological study which revealed affinities with contemporary pottery from north west France.

Sandy fabrics, containing no geologically distinctive inclusions may still usefully be examined as thin sections in the petrographic microscope. The approach used is frequently referred to as textural analysis (Peacock, 1971; Middleton et al., 1985); it involves the assessment of features such as the abundance and size distribution of the sand grains, their shape (sphericity) and degree of angularity. These features will vary, depending upon factors such as the sources of the raw clay and any sandy material added as temper, as well as on any modification of the raw materials during processing into a clay paste suitable for potting. Thus, one fabric might be characterised by the presence of abundant, well-rounded, coarse quartz sand, whilst another might contain a lower proportion of finer, more angular quartz sand. By revealing these

to successively higher temperatures. By comparison with samples exposed to known temperatures in a laboratory furnace, it is possible to estimate the maximum temperatures to which archaeological ceramics have been exposed. 

1997.

differences, textural analysis may permit the two fabrics to be distinguished, even when there are no diagnostic mineralogical differences.

However, textural analysis can be timeconsuming (and tedious!) to carry out, even with a semi-automatic image analyser, and the number of such studies is relatively few. In a study of Romano-British tiles from southern England (which contained no distinctive inclusions) we resorted to a less formal mode of analysis which we termed attribute analysis (Middleton et al., 1991). This permitted the grouping of the tile sherds by features (attributes) such as the coarseness and abundance of the silty/sandy inclusions, and the abundance of mica, clay pellets, etc., opaque grains. These groupings were necessarily tentative but when supported by chemical analysis of the clay fabrics by neutron activation analysis (NAA) permitted the tiles to be divided into a number of fabric groups. It was then possible to relate these to examples from known kiln sources and to draw some conclusions concerning the organisation of Roman tile production and distribution in Southern England (Middleton et al., 1992).

\section{Conclusions}

Petrographic analysis, involving the description and characterisation of ceramic fabrics in thin section can make a valuable contribution to the study of archaeological ceramics. It is a destructive technique, requiring the removal of a coherent slice of material; but this can be taken from broken sherds which are often plentiful. It is important, though that samples for petrographic analysis are carefully selected and the ability of petrography to answer the questions being asked of the pottery assessed carefully from the outset. There is an inherent variability in the pastes of vessels made from the same clay and as a general rule it is usually advisable to examine from 5 to 10 examples from each fabric group, in order to define the variations within each group. It is therefore often useful to undertake a small scale pilot study before embarking on a full scale programme of analysis.

The examination of thin sections may provide information on pottery technology (raw material selection and preparation, forming techniques and firing), but its main contributions have been to the characterisation of clay pastes, providing a means by which to associate groups of pots with a particular provenance. In this context it has often been used to good effect when combined with some form of chemical analysis. However, petrology has the unique ability to predict the source by the recognition of characteristic inclusions, which can be associated with particular outcrops of geologically distinctive rocks.

The level of success of petrographic analysis projects will depend upon several factors, which may include the degree and scale of variability in the underlying geology of the area/region of study, and the techniques used by the ancient potters to select and prepare their clay pastes: very fine pastes may not be amenable to informative petrographic study. Often it will be appropriate to support and refine petrographic data with information from other techniques of analysis, such as chemical analysis, examination in the SEM or radiographic examination. Fully integrated studies, employing several techniques to investigate different aspects of the archaeological ceramic assemblage often yield the most useful results, but perhaps the most fundamental need is for proper collaboration between archaeologist and analyst. In this way, questions to be addressed can be defined at an early stage and the analytical data placed in their archaeological framework, allowing meaningful and useful interpretation. 
MIDDLETON, A. Ceramic petrography. Rev. do Museu de Arqueologia e Etnologia, São Paulo, Suplemento 2: 73-79, 1997.

MIDDLETON, A. Ceramic petrography. Rev. do Museu de Arqueologia e Etnologia, São Paulo, Suplemento 2: 73-79, 1997.

ABSTRACT: The chief aim of this paper is to indicate the potential of ceramic petrography to provide archaeologically useful information on ancient ceramics. The practicalities of the technique are outlined, in particular the need for destructive sampling of pottery sherds. Some historical background highlighting some of the early applications of ceramic petrography is also given. The capabilities (and limitations) of the method in the study of pottery technology and in the determination of provenance are then discussed, and illustrated by reference to published case studies.

UNITERMS: Ceramic petrography — Ceramic technology — Ceramic provenience.

\section{References}

ADAMS, A.E.; MACKENZIE, W.S.; GUILFORD, C.

1984 Atlas of Sedimentary Rocks under the microscope. Longman, London.

COURTY, M.A.; ROUX, V.

1995 Identification of wheel-throwing on the basis of ceramic surface features and microfabrics. Journal of Archaeological Science, 22: 17-50

CUOMO DI CAPRIO, N.; VAUGHAN, S.J.

1993 An experimental study in distinguishing grog (chamotte) from argillaceous inclusions in ceramic thin sections. Journal of Archaeological Science, 7: 21-40.

FABBRI, B. (Ed.)

1995 The Cultural Ceramic Heritage. Fourth Euro Ceramics, 14. Faenza.

FREESTONE, I.C.

1995 Ceramic petrography. American Journal of Archaeology, 99: 111-115.

FREESTONE, I.C.; JOHNS, C.; POTTER, T. (Eds.)

1982 Current Research in ceramics: thin-section studies. British Museum Occasional Paper 32, British Museum, London.

FREESTONE, I.C.; MIDDLETON, A.P.

1987 Mineralogical applications of the analytical SEM in archaeology. Mineralogical Magazine, 51: 21-31.

FREESTONE, I.C.; RIGBY, V.

1982 Class B cordoned and other imported wares from Hengisbury Head, Dorset. In I.C. Freestone et al. (Eds) Current Research in ceramics: thin-section studies. British Museum Occasional Paper 32, British Museum, London: 29-41.

HUTCHINSON, C.S

1974 Laboratory Handbook of Petrographic Techniques. Wiley, New York.
MACKENZIE, W.S.; ADAMS, A.E.

1994 Rocks and Minerals in Thin Section. Manson Publishing, London.

MACKENZIE, W.S.; DONALDSON, C.H.; GUILFORD, D.

1982 Atlas of Igneous Rocks and their Textures. Longman, London.

MACKENZIE, W.S.; GUILFORD, C.

1980 Atlas of Rock-forming Minerals in Thin Section. Longman, London.

MANIATIS, Y.; TITE, M.S.

1981 Technological examination of Neolithic-Bronze Age pottery from central and south-east Europe and from the Near East. Journal of Archaeological Science, 8: 59-76.

MERY, $S$.

1992 Science de la Terre et Céramique Arquéologique. Documents et Travaux, Institut Géologique Albert Lapparent, 16, Cergy.

MIDDLETON, A.P

1997 Ceramics. In J. Lang and A. Middleton (Eds.) Radiography of Cultural Materials. Butterworth-Heinemann, Oxford.

MIDDLETON, A.P.; COWELL, M.R.; BLACK, E.

1992 Romano-British relief-patterned flue tiles: a study of provenance using petrography and neutron activation analysis. S. Méry (Ed.) Science de la Terre et Céramique Arquéologique. Documents et Travaux, Institut Géologique Albert Lapparent, 16, Cergy.

MIDDLETON, A.P.; FREESTONE, I.C. (Eds.)

1991 Recent Developments in Ceramic Petrology, British Museum Occasional Paper 81, British Museum, London.

MIDDLETON, A.P.; FREESTONE, I.C.; LEESE, M.N.

1985 Textural analysis of ceramic thin sections: evaluation of grain sampling procedures. Archaeometry, 27: 64-74. 
MIDDleton, A. Ceramic petrography. Rev. do Museu de Arqueologia e Etnologia, São Paulo, Suplemento 2: 73-79, 1997.

MIDDLETON, A.P.; LEESE, M.N.; COWELL, M.R.

1991 Computer-assisted approaches to the grouping of ceramic fabrics. A.P. Middleton e I.C. Freestone (Eds.) Recent Development in Ceramic Petrology. British Museum Occasional Paper 81. British Museum, London: 265-276.

PEACOCK, D.P.S.

1969 A contribution to the study of Glastonbury ware from South-western Britain. Antiquities Journal, 49: 41-61.

1970 The scientific analysis of ancient ceramics: a review. World Archaeology, 1: 375-389.

1971 Petrography of certain coarse pottery. B. Cunliffe (Ed.) Excavations at Fisbourne, Report of the Research Committee of the Society of Antiquaries, 27, London: 255-259.

RICE, P.M.

1987 Pottery Analysis: A Sourcebook. London. RIGBY, G.R.

1948 The Thin-section Mineralogy of Ceramic Materials. British Refractories Research Association.

RYE, O.S.

1976 Keeping your temper under control: materials and the manufacture of Papuan pottery. Archaeology and Physical Anthropology in Oceania, 11: 106-137.

1977 Pottery manufacturing techniques: X-ray studies. Archaeometry, 19: 205-211.

SHEPARD, A.O.

1942 Rio Grande Glaze Paint Ware, a study illustrating the place of Ceramic Technological Analysis in Archaeological Research. Carnegie Institution, Washington.
1956 Ceramics for the Archaeologist. Carnegie Institution, Washington.

1966 Rio Grande Glaze-Paint pottery: a test of petrographic analysis. F.R. Matson (Ed.) Ceramics and Man, London: 62-87.

SIMCOCK, J.H.

1956 The polarising microscope in a work laboratory. British Ceramic Society Transactions, 55: 204226.

VAUGHAN, $S$.

1995 Ceramic petrology and petrography in the Aegean. American Journal of Archaeology, 99: 115-117.

WHITBREAD, I.K

1986 The characterisation of argillaceous inclusions in ceramic thin sections. Archaeometry, 28: $79-88$.

WOODS, A

1982 Smoke gets in your eyes: patterns, variables and temperature measurement in open firings. Bulletin of the Experimental Firing Group, I: 11-25.

1985 An introductory note on the use of tangential thin sections for distinguishing between wheelthrown and coil/ring-built vessels. Bulletin of the Experimental Firing Group, 3: 100-114.

1986 Form, fabric and function: some observations on the cooking pot in antiquity. W.D. Kingery (Ed.) Ceramics and Civilisation II. Technology and Style. American Ceramics Society, Westerville, Ohio: 157-172.

YARDLEY, B.W.D.; MACKENZIE,W.S.; GUILFORD, C.

1990 Atlas of Metamorphic Rocks and their Textures. Longman, London. 